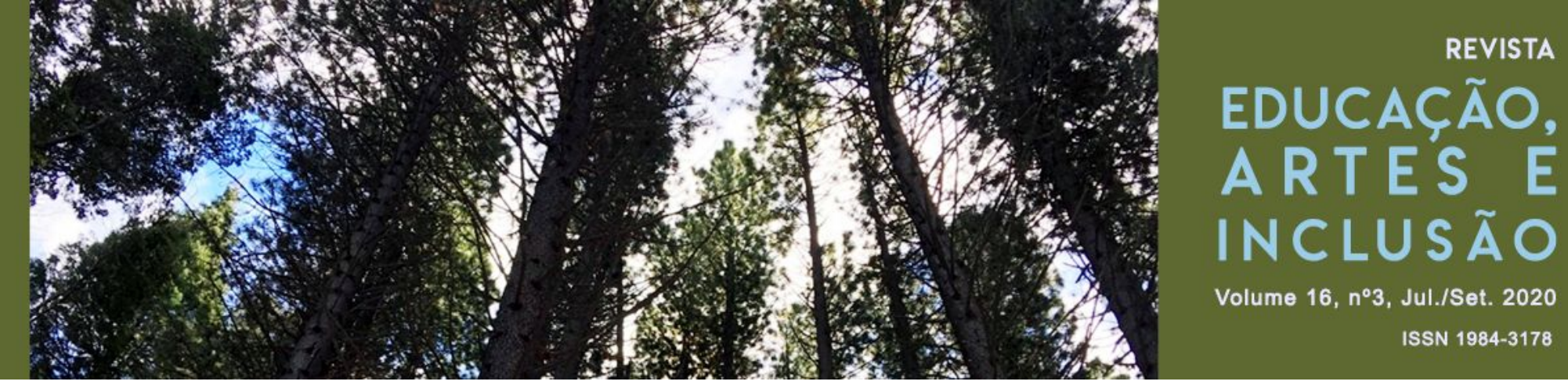

\title{
Jogo cooperativo de ciências: o ensino de Libras para alunos ouvintes do quinto ano
}

\section{Cooperative science game: the teaching of Libras to listening students of the fifth year}

DOI: http://dx.doi.org/10.5965/198431781632020267

\author{
Clevia Bittencurt Ersching \\ Universidade do Estado de Santa Catarina \\ cleviabe@yahoo.com.br
}

Fabíola Sucupira Ferreira Sell

Universidade do Estado de Santa Catarina

fabiolafsell@gmail.com | ORCID

\section{RESUMO}

Este estudo tem por objetivo geral a análise do jogo cooperativo como ferramenta para o ensino de Libras para alunos ouvintes do quinto ano, na disciplina de Ciências, em cuja escola há alunos surdos matriculados. Sabe-se que o ensino de Libras para ouvintes é algo recente, e a valorização desta língua é fundamental para contribuir na inclusão de surdos na sociedade como um todo. Esta pesquisa delineia-se como sendo qualitativa, por meio de um estudo de campo. A amostra se configura em 20 alunos de uma turma de quinto ano de uma escola municipal da cidade de Guaramirim. Com a aplicação do jogo cooperativo verificou-se que este, por estimular atitudes de companheirismo e parceira, contribuiu para o ensino e aprendizagem de Libras bem como do conteúdo sobre reciclagem de materiais. Além disso, os alunos relataram que gostaram do jogo e que se sentiram estimulados a realizar as atividades propostas por cada casa do jogo.

Palavras-chave: Jogo Cooperativo. Ensino de Libras. Reciclagem. Alunos Ouvintes.

\section{ABSTRACT}

The main objective of this study is the analysis of the cooperative game as a tool for teaching Libras (Brazilian Sign Language) to fifth-grade hearing students, in Science classes, in which school a deaf student is enrolled. It is known that teaching Libras to hearing people is something recent, and the appreciation of this language is fundamental to contribute to the inclusion of deaf people in society as a whole. This research is outlined as qualitative, through a field study. The sample consists of a class of 20 fifth-grade students at a municipal school in the city of Guaramirim. With the application of the cooperative game it was found that this, by stimulating attitudes of companionship and partnership, contributed to the teaching and learning of Libras as well as the content of recycling. Moreover, the students reported they liked the game and they felt encouraged to carry out the activities proposed by each game space.

Keywords: Cooperative Game; Libras Teaching; Recycling; Hearing Students. 
